\title{
TOIMINTATERAPIA IHMISEN TOIMINNAN JA OSALLISTUMISEN MAHDOLLISTAJANA
}

\section{Johdanto}

Toimintaterapiaa on käytetty kuntoutusmuotona tilanteissa, joissa pitkäaikaissairaudet, traumat, kehityshäiriöt ja ikääntyminen sekä erilaiset siirtymät elämäntilanteesta ja -vaiheesta toiseen ovat aiheuttaneet vaikeuksia selviytyä itsenäisesti tavallisista arkitoiminnoista ja rutiineista. Toisaalta toimintaterapiaa tarvitaan ympäristön muokkaamiseen silloin, kun fyysiset tai sosiaaliset ympäristötekijät estävät ihmisen mahdollisuuksia käyttää kykyjään, elää itsenäisesti, opiskella ja tehdä työtä sekä kokea arvostusta omassa lähipiirissä ja yhteisössä. Toimintaterapian tarvetta ovat lisänneet myös monet elämäntapoihin liittyvät ongelmat, kuten päihteiden käyttö, sekä työttömyys, syrjäytyminen ja maahanmuuttoon liittyvät sosiaaliset vaikeudet, jotka haittaavat ihmisen mahdollisuuksia huolehtia itsestään ja läheisistään.

Toimintaterapiassa toimintaa koskevat käsitykset perustuvat toiminnan tieteeseen, jossa on tutkittu toiminnan ja toimintakykyisyyden rakentumista toimijan, toimintaympäristön ja toiminnan jatkuvasti muuttuvana vuorovaikutteisena prosessina. Toimintaterapiassa on tutkittu pitkään monia, tällä hetkellä suomalaisessa ja kansainvälisessä sosiaali- ja terveydenhuollossa ahkerasti käytettyjä käsitteitä, kuten asiakaskeskeisyyttä, arkea, asiakkaan oikeutta osallistua itseään koskevaan päätöksentekoon ja oman kuntoutuksensa suunnitteluun sekä valinnanvapautta.
Nykyisin toimintaterapeuttien osaamista on alettu kaivata yhä moninaisemmissa yhteyksissä hyvien toimintaympäristöjen ja -kulttuurien rakentamisessa ja erityisesti käyttäjälähtöisessä innovaatiotoiminnassa. Mitä siis on toimintaterapian koulutuksen ydinosaaminen?

\section{Ihminen, toiminta ja ympäristö toimintaterapian koulutuksen ytimessä}

Toimintaterapian peruskäsitteet ihminen, toiminta ja ympäristö näkyvät kaikkien ammattikorkeakoulujen opetussuunnitelmissa. Poikkitieteellisyyttä tarvitaan ihmisen toiminnan kokonaisvaltaisessa ymmärtämisessä. Jotta toimintaterapeutit oppivat ymmärtämään sekä toimintaan vaikuttavat että siitä aiheutuvat tekijät, toimintaterapian lisäksi on opiskeltava muun muassa anatomiaa, fysiologiaa, psykologiaa, lääketiedettä sekä ihmisen kehittymistä. Ympäristöä on tarkasteltava laajasti yhtäältä toimintaa mahdollistavana ja toisaalta sitä haittaavana tai estävänä tekijänä. Sen lisäksi opinnoissa tutkitaan ympäristön, ihmisen toiminnan ja hyvinvoinnin välisiä merkityssuhteita. Ympäristöosaamista lisätään myös perehtymällä apuvälineiden ja ympäristön muokkaamisen tarjoamiin teknologisiin ja sosiaalisiin mahdollisuuksiin, joiden avulla tuetaan asiakkaan toiminnallisuutta ja osallisuutta. 
Toimintaterapeutti on ihmisen toiminnan asiantuntija. Toimintaterapialla pyritään mahdollistamaan ihmiselle osallistuminen hänelle merkityksellisiin toimintoihin, sillä sen uskotaan edistävän terveyttä ja hyvinvointia. Kun ihminen saa vapaasti valita ja tehdä itselleen merkityksellisiä asioita, hän voi kokea hallinnan, kontrollin ja itsemääräämisoikeuden tunnetta.

Toimintaa tarkastellaan opetussuunnitelmissa laajasti suhteessa yhteiskuntaan, ihmisen elämään sekä hyvinvointiin. Näin halutaan luoda opiskelijoille vankka kuva toiminnan merkityksestä ihmiselle sekä ymmärrys siitä toimintaterapian keskeisenä päämääränä. Toimintaterapeutti käyttää toimintaa osana arviointi- ja terapiaprosessia. Erilaisia toimintoja ja toimintamuotoja käytetään opetuksessa myös pedagogisena välineenä. Opetussuunnitelmissa toimintamuodot näyttäytyvät pääosin valinnaisten opintojen osana. Sen sijaan monissa opetussuunnitelmissa näkyy ryhmän terapeuttinen käyttö ja ohjaaminen omana kokonaisuutenaan.

Toimintaterapeutin tehtävä on mahdollistaa asiakkaan toimintaa ja jokapäiväiseen elämään osallistumista toimintakyvyn arvioinnin ja toiminnan kautta sekä mahdollistaa ihmisille terveyttä ja hyvinvointia edistävää toimintaa. Tehtävänä on myös mahdollistaa oikeudenmukainen ja mukaan ottava yhteiskunta siten, että kaikilla ihmisillä olisi mahdollisuus osallistua ja käyttää kyvykkyyttään omassa elämässään. (Townsend Et Polatajko 2013.) Ihmisen arki ja arjessa kuntoutuminen ovat toimintaterapian koulutuksessa keskeisessä asemassa.

Toimintaterapiaa toteutetaan yksilö-, perhe-, pari-, ryhmä- ja yhteisömuodoissa. Asiakkaiden ainutlaatuisuuden kohtaaminen edellyttää jokaisen ihmisen yksilöllisyyden tunnistamista sekä asiakkaan autonomian ja itsemääräämisoikeuden kunnioittamista. Siitä syntyy pohja asiakkaan/asiakkaiden/perheen ja toimintaterapeutin väliselle yhteistoiminnalle. Yhteistoiminta vahvistaa toimijoiden asiantuntijuutta ja sitoutumista.

Toimintaterapiaprosessi näyttäytyy opetussuunnitelmissa asiakkaan toiminnan tai toimintakyvyn arviointiin sekä terapiainterventioon liittyvien opintojen kautta. Kunkin ammattikorkeakoulun painotukset näkyvät siinä, miten toimintaterapian toteuttamiseen liittyvät opinnot on rakennettu ja nimetty. Opetussuunnitelmien mukaan toimintaterapian avulla pyritään osallisuuden tukemiseen, toiminnan mahdollistamiseen, toimintamahdollisuuksien tukemiseen, toimintakyvyn edistämiseen sekä toiminnallisuuden edistämiseen. Osa opetussuunnitelmista rakentuu elämänkaaren mukaan niin, että toimintaterapian opinnot on jäsennetty lasten, työikäisten ja ikääntyvien mukaan. Osassa opinnot on jäsennetty itsestä huolehtimisen, työn ja tuottavuuden sekä vapaaajan toimintojen avulla.

Toimintaterapia sitoutuu lähes kaikissa opetussuunnitelmissa kuntoutukseen, jota tarkastellaan joko omana kokonaisuutenaan tai sosiaali- ja terveydenhuollon tehtävänä. Opetussuunnitelmissa näkyvät myös kuntoutuksessa nykyisin laajasti vallalla olevat lähestymistavat, kuten asiakaslähtöisyys sekä näyttöön perustuva käytäntö.

Toimintaterapiassa tarkastellaan ympäristöä laaja-alaisesti fyysisten, sosiaalisten ja kulttuuristen tekijöiden avulla. Toimintaterapeutin tehtävänä on tunnistaa, lieventää tai poistaa ne esteet, jotka haittaavat tai estävät asiakkaan toimintaa, sekä rakentaa välineitä ja ympäristöjä, jotka mahdollistavat tai helpottavat hänen toimintaansa.

Virtuaaliset toimintaympäristöt haastavat toiminnan asiantuntijoita etsimään uudenlaisia näkökulmia ihmisenä olemiseen, kohtaamiseen ja kuntoutumiseen. Toimiminen automatisoituneessa ympäristössä muuttaa toiminnalle annettavia yksilöllisiä merkityksiä sekä toimintamahdollisuuksia. Teknologian kehityksen ohella ihmisten toimintakulttuurit monimuotoistuvat ja toimintaympäristöt muokkaavat työtehtäviä. Toimintaterapeutin toiminnan analysointitaito auttaa tunnistamaan ja hyödyntämään muuttuvia ympäristöjä ja toiminnan muutoksia sekä niiden edellyttämää osaamista ja kyvykkyyttä. Se on tärkeä osa myös tuotteiden ja palvelujen kehittämistä. 
Kansainväliset opettaja- ja opiskelijavaihdot ovat oleellinen osa toimintaterapian koulutusta. Yhteistyö ja kansainvälistyminen vahvistavat opiskelijoiden osaamista monikulttuurisissa ja kansainvälisissä ympäristöissä ja lisäävät heidän kilpailukykyään työmarkkinoilla valmistumisen jälkeen. Ne myös vahvistavat työvoiman kansainvälistä liikkuvuutta.

\section{Toimintaterapian osaamisen rakentuminen ammattikorkeakoulutuksessa}

Toimintaterapian ammattikorkeakoulututkinnon lähtökohtana on osaamisperustainen opetussuunnitelma, jossa osaaminen kuvataan neutraaleina oppimistuloksina (learning outcomes). Osaamisen tasoa kuvaavat kriteerit määrittelevät sekä hyväksyttävän tason että muut tutkinnossa määriteltävät osaamisen tasot. Kriteerit mahdollistavat opiskelijalle henkilökohtaisen opiskelusuunnitelman ja vaihtoehtoisten suoritustapojen suunnittelun ja toteuttamisen. (Raij 2003; Saranpää 2012.)

Ammattikorkeakouluilla on itsenäinen vapaus rakentaa toimintaterapiakoulutusten opetussuunnitelmat. Toimintaterapian opetussuunnitelmille on yhteistä se, että niitä raamittavat kansallisten ja alueellisten ohjeistojen lisäksi kansainväliset ja Euroopan sisäiset ohjeet. Toimintaterapeuttien maailmanliitto (World Federation of Occupational Therapists, WFOT) julkaisi vuonna 2002 uusimmat toimintaterapeuttien koulutuksen kansainväliset minimistandardit (WFOT Minimum Standards for the Education of Occupational Therapists). Niissä määritellään muun muassa opetussuunnitelman sisältö, tavoitteet, toimintaterapian teoriaperusta, opettajien pätevyydet, käytännön harjoittelujen laajuus ja sisältö.

Kaikki Suomen toimintaterapiakoulutukset noudattavat WFOT:n minimistandardeja. Suomen toimintaterapeuttiliitto ry. monitoroi viiden vuoden välein minimistandardien toteutumista. Toimintaterapiakoulutusten kansainvälinen yhtenäistäminen ja vertailukelpoisuus toteutuu yhteistyöelin ENOTHEn (The European Network of Occupational Therapy
Higher Education) myötä. ENOTHE on Euroopan toimintaterapiakoulutusten korkeakouluverkosto, jonka tavoitteena on saada koulutukset keskenään vertailukelpoisiksi Euroopassa. Tämä edellyttää yhteisen perustan ja käsitteistön löytymistä opetussuunnitelman pohjaksi sekä opetussuunnitelmien kirjaamista yhdenmukaisella tavalla siten, että niistä on helposti poimittavissa niiden rakenteeseen ja sisältöön liittyvät asiat.

Eurooppalainen tutkintojen viitekehys (EQF, European Qualifications Framework) helpottaa Euroopan maissa suoritettujen tutkintojen vertailua. Kansallinen tutkintojen viitekehys (NQF, National Qualifications Frameworks) kuvaa Suomessa suoritettavia tutkintoja ja pätevyyksiä. Näiden viitekehysten tavoitteena on selkiyttää tutkintojen vastaavuuksia ja auttaa pätevyyksien tunnistamisessa.

\section{Työelämäyhteys sekä tutkimus-, kehittämis- ja innovaatiotoiminta}

Toimintaterapiassa työelämäyhteyttä rakennetaan ja ylläpidetään vahvasti käytännön harjoittelun avulla, sillä sen osuus koko tutkinnosta (210 op) on 75 opintopistettä. Osa harjoittelusta tapahtuu käytännöllisten aineiden myötä koululla, osa ohjattuna työelämässä. Työelämässä tehtävän harjoittelun laajuus vaihtelee eri ammattikorkeakouluissa 35 opintopisteestä 51 opintopisteeseen. Harjoittelujaksot sijoittuvat tasaisesti eri lukuvuosille.

Ohjatut harjoittelujaksot toteutuvat sosiaali- ja terveydenhuollon laitoksissa, kouluissa ja päiväkodeissa, yrityksissä ja erilaisissa yhteisöissä. Harjoittelu voi toteutua myös terveyttä ja hyvinvointia edistävissä organisaatioissa ja yhteisöissä, joissa opiskelijat osallistuvat kaupunkien ja kuntien kehittämiseen. Harjoittelutoiminnassa syntyneet vahvat suhteet työelämään mahdollistavat ajankohtaisen tiedon saamisen työelämän kehittämistarpeista ja luovat vankan perustan mielekkäälle alueelliselle kehittämisyhteistyölle.

Ammattikorkeakoululain (932/2014) mukaan pedagogiikassa tulee yhdistyä pedagoginen, tutkimus- ja kehittämistoiminta sekä alueellinen yhteistyö elinkeinoelämän kanssa. 
Vastatakseen näihin haasteisiin toimintaterapiakoulutukset tarjoavat erilaisia oppimisympäristöjä todellisissa työelämän konteksteissa. Projektioppiminen ja kehittämistoiminta aidossa työelämän ympäristössä tarjoavat opiskelijoille mahdollisuuden mielekkääseen oppimiseen.

Työelämän käytäntöjen kehittämiseen tähtäävän, näyttöön perustuvan toimintaterapian (evidence-based occupational therapy) edellyttämä tiedonhankinta, arviointi ja hyödyntäminen opiskellaan koulutuksen aikana. Tämä luo pohjan sille, että toimintaterapiapalvelut perustuvat parhaaseen saatavilla olevaan tietoon. Myös koulutuksen aikana tehtävä opinnäytetyö (laajuus 15 op) vahvistaa toimintaterapiapalvelujen kehittämisessä tarvittavia taitoja. Samalla opinnäytetöiden työelämäyhteys rakentaa koko ajan alan kehittämistoimintaa. Toimintaterapiassa opinnäytetyö voi olla luonteeltaan kehittämistehtävä, tuotekehitys-, soveltava tutkimus- tai projektityö, ja se toteutetaan yhteistyössä työelämän toimijoiden kanssa.

Toimintaterapian koulutukset osallistuvat korkeakoulujen ydintoimintojen toteuttamiseen ja ammattikorkeakoulujen tulostavoitteiden saavuttamiseen. Lisäksi ne osallistuvat liiketoimintana tapahtuvaan koulutuksen tuottamiseen, tutkimus-, kehitys- ja innovaatiotoimintaan sekä kansainvälistymiseen. Vuonna 2015 kansainväliseen vaihtoon lähti 88 opiskelijaa ja opettajaa, ja Suomeen tuli 59 kansainvälistä opiskelijaa ja opettajaa (taulukko 1).

\section{Koulutuksen laadun varmistaminen}

Suomessa kansallinen koulujen arviointikeskus (Karvi) on arvioinut kaikki suomalaiset yliopistot ja ammattikorkeakoulut vuosina 2005-2012. Nyt käynnissä oleva toinen auditointikierros jatkuu vuoteen 2018 saakka. Auditoinneilla tuetaan korkeakoulujen kehittämistä vastaamaan eurooppalaisia laadunvarmistuksen periaatteita. Kukin korkeakoulu saa kuitenkin päättää laatujärjestelmänsä tavoitteista, rakenteesta, toimintaperiaatteista, käytettävistä menetelmistä ja laadunhal- linnan kehittämisestä. Kaikissa suomalaisissa korkeakouluissa toimintaterapian koulutus täyttää yleisten, suomalaisille korkeakouluille asetettujen vaatimusten lisäksi myös kansainväliset toimintaterapiakoulutukselle asetetut standardit.

Auditointien lisäksi korkeakoulut hyödyntävät toiminnan kehittämisessä itsenäisesti arviointi- ja palautejärjestelmistä (esimerkiksi opiskelijapalautteista, asiakaspalautteista, sidosryhmäkyselyistä, alumnikyselyistä, ohjaus- ja asiantuntijaryhmistä sekä neuvottelukunnista) saatua tietoa niin, että toiminta vastaisi asiakkaiden tarpeisiin parhaalla mahdollisella tavalla. Kaikki toimintaterapiakoulutukset hyödyntävät saamiaan arvioita ja palautteita oman toimintansa kehittämisessä.

Sisällöllisesti toimintaterapian koulutuksen laatuun vaikuttaa saatavilla oleva tutkimus- ja teoriatieto. Opetuksessa hyödynnetään pääasiassa ulkomaisia tutkimuksia ja teorioita. Toimintaterapian tutkimuksen ja teorioiden lisäksi toiminnan tiede tuottaa toimintaterapian koulutukseen ymmärrystä toiminnan terapeuttisesta luonteesta ja empiiristä näyttöä toiminnan terapeuttiselle käytölle toimintaterapiassa. Toimintaterapiassa tehtävä tutkimus kohdistuu pääasiassa toimintaterapian vaikuttavuuteen, koulutukseen, menetelmien kehittämiseen ja niiden käytettävyyden ja luotettavuuden testaamiseen. Lisäksi tutkimus kohdistuu toimintaterapian onnistumisen kannalta keskeisiin ilmiöihin, kuten toiminnan, ympäristön ja toimijan välisiin suhteisiin sekä terapiasuhteen rakentamiseen. Paine suomalaisen tutkimustiedon tuottamiseksi tulee seuraavien vuosien aikana todennäköisesti lisääntymään.

Toimintaterapian koulutukset ovat ympäri maata olleet vetovoimaisia, läpäisyaste on ollut hyvä ja toimintaterapeuttien työllistyminen koulutustaan vastaavaan työhön on onnistunut erinomaisesti. Vuonna 2015 viidestä ammattikorkeakoulusta valmistui 750 toimintaterapeuttia. Urakehityksen kannalta jatkokoulutusmahdollisuudet ovat tärkeitä. Ammattikorkeakoulujen tarjoamat kuntoutuksen ylemmät tutkinnot ovat olleet suosittuja, samoin vuonna 2017 loppumassa oleva kuntoutustieteen pääaineopiskelu Lapin yli- 
Taulukko 1. Ammattikorkeakoulujen toimintaterapian koulutuksen opiskelijamäärät, valmistuneet ja kansainväliseen vaihtoon saapuneet ja lähteneet opiskelijat ja henkilökunnan jäsenet vuonna 2015.

\begin{tabular}{|c|c|c|c|c|c|c|}
\hline & \multicolumn{2}{|c|}{ Opiskelijamäärä 2015} & \multirow{2}{*}{$\begin{array}{l}\text { Opiskelija- } \\
\text { määrä } \\
2015 \\
\text { yhteensä }\end{array}$} & \multirow{2}{*}{$\begin{array}{l}\text { Valmistu- } \\
\text { neiden } \\
\text { määrä } \\
2015\end{array}$} & \multicolumn{2}{|c|}{$\begin{array}{l}\text { Kansainväliset vaihdot } 2015 \\
\text { hk = henkilökunta } \\
\mathrm{o}=\text { opiskelija }\end{array}$} \\
\hline & $\begin{array}{l}\text { Päivä- } \\
\text { opetus }\end{array}$ & $\begin{array}{l}\text { Monimuoto- } \\
\text { opetus }\end{array}$ & & & Tulevat & Menevät \\
\hline Arcada & 64 & 0 & 64 & 16 & $\begin{array}{l}6 \mathrm{hk} \\
2 \mathrm{o}\end{array}$ & $\begin{array}{l}4 \mathrm{hk} \\
8 \mathrm{o}\end{array}$ \\
\hline $\begin{array}{l}\text { Metropolia } \\
\text { Amk }\end{array}$ & 154 & 74 & 228 & 56 & $\begin{array}{l}7 \mathrm{hk} \\
120\end{array}$ & $\begin{array}{l}10 \mathrm{hk} \\
17 \mathrm{o}\end{array}$ \\
\hline $\begin{array}{l}\text { Jyväskylän } \\
\text { amk JAMK }\end{array}$ & 144 & 40 & 184 & 32 & $\begin{array}{l}2 \mathrm{hk} \\
8 \mathrm{o}\end{array}$ & $\begin{array}{l}2 \mathrm{hk} \\
11 \mathrm{o}\end{array}$ \\
\hline $\begin{array}{l}\text { Oulun amk } \\
\text { OAMK }\end{array}$ & 124 & 0 & 124 & 23 & $\begin{array}{l}6 \mathrm{hk} \\
8 \mathrm{o}\end{array}$ & $\begin{array}{l}9 \mathrm{hk} \\
20 \mathrm{o}\end{array}$ \\
\hline $\begin{array}{l}\text { Turun amk } \\
\text { TUAMK }\end{array}$ & 103 & 47 & 150 & 31 & $\begin{array}{l}2 \mathrm{hk} \\
6 \mathrm{o}\end{array}$ & $\begin{array}{l}2 \mathrm{hk} \\
5 \mathrm{o}\end{array}$ \\
\hline Yhteensä & 589 & 161 & 750 & 158 & 59 & 88 \\
\hline
\end{tabular}

opistossa. Yliopistotasoisen toimintaterapian pääaineopetuksen ja oman alan tutkijakoulutuksen puuttuminen suomalaisista yliopistoista uhkaa alan kehitystä Suomessa. Onneksi yhä useampi tutkimuksesta ja urakehityksestä kiinnostunut toimintaterapeutti on tarttunut ulkomaisten yliopistojen tarjoamiin jatkotutkintomahdollisuuksiin verkko- ja etäopiskeluna.

\section{Pohdinta}

Toimintaterapiakoulutusten monipuoliset ja moniammatilliset opetusmenetelmät huomioivat erilaiset oppijat ja edistävät opiskelijoiden oppimisprosessia. Ne myös edistävät vuorovaikutusta opiskelijoiden ja opettajien sekä oppijoiden kesken. Pedagogisten ratkaisujen lähtökohtana on opiskelijakeskeinen oppiminen, jossa dialogi ja verkko-opinnot ovat välttämättömiä opiskelijan osaamisen kehittämiseksi. Erilaisten didaktisten ratkaisujen valinnat juontavat kuitenkin aina osaamistavoitteista.
Sosiaali- ja terveyspalvelujen (sote) uudistusprosessi ja yhteiskunnallinen kehitys ovat jo vaikuttaneet huomattavasti toimintaterapiakoulutukseen. Aiemmin koulutus tähtäsi asiantuntijoiden tuottamiseen julkisten palveluntuottajien tarpeisiin, mutta tulevaisuudessa yhä useampi toimintaterapeutti tulee toimimaan yrittäjänä tai yksityisen sektorin palveluksessa. Toimintaterapeutit voivat työllistää itsensä toiminnan asiantuntijoina mitä moninaisimmissa tehtävissä, siksi lääkinnällinen kuntoutus on jo nyt vain yksi tärkeä toimintaterapeutin työmahdollisuus. Koulutukselle nämä muutokset asettavat isoja haasteita erityisesti yrittäjyys- ja innovaatio-osaamisen vahvistamiseksi niin, ettei kuitenkaan menetetä toimintaterapeutin työssä tarvittavaa substanssiosaamista.

Toimintaterapiakoulutuksissa on tunnistettu, että toimintaterapeutti käyttää omaa persoonaansa tietoisesti ja tavoitteellisesti vuorovaikutusprosessissa asiakkaan kanssa. Tietoisuus itsestä ja omasta osaamisesta kehittyy vain reflektion myötä. Toimintatera- 
peutiksi kehittyminen ja kasvaminen on pitkä ja vaativa prosessi, joka saa alkunsa koulutuksen aikana. Koulutuksessa opiskelijoita haastetaan tutustumaan itseensä, omiin vahvuuksiinsa ja omiin kehittymisalueisiinsa. Heitä houkutellaan ja vaaditaan vahvistamaan omaa reflektiotaitoaan, sillä se on terapiatyössä asiantuntijuuden vahvistumisen välttämätön ehto. Erilaisten toiminnallisten menetelmien käyttäminen esimerkiksi opiskelijaryhmässä edistää opiskelijan reflektointikykyä.

Eettinen toiminta on toimintaterapiatyön perusta. Toimintaterapiakoulutuksessa eettisyys on läsnä yhtä lailla opetuksessa, olemisessa, vuorovaikutuksessa, tekemisessä ja tekemättä jättämisessä. Toimintaterapeuttia ohjaavat Suomen toimintaterapeuttiliiton laatimat eettiset ohjeet ja yleiset eettiset periaatteet, kuten ihmisarvon ja ihmisoikeuksien kunnioittaminen.

Toini Harra, YTT, FL, yliopettaja, Metropolia Ammattikorkeakoulu

Annikki Arola, MSc, lehtori, Yrkeshögskolan Arcada

Tiina Hautala, KL, yliopettaja, Turun ammattikorkeakoulu

Denice Haldin, KM, lehtori, tutkintovastaava, Yrkeshögskolan Arcada

Tiina Lautamo, FT, yliopettaja, Jyväskylän ammattikorkeakoulu Oy

Kaija Nevalainen, TtM, lehtori, tutkintovastaava, Oulun Ammattikorkeakoulu Oy

\section{Kirjallisuus}

Ammattikorkeakoululaki (932/2014).

COTEC Councel of Occupational Therapists for the European Countries (http://www.coteceurope.eu/) ENOTHE The European Network of Occupational Therapy Higher Education. (http://enothe.eu)

Karvi (2016) Kansallinen koulujen arviointikeskus. (http://karvi.fi/publication/korkeakoulujenlaatujarjestelmien-auditointikasikirja-vuosiksi-2015-2018/)

OPM (2009) Tutkintojen ja muun osaamisen kansallinen viitekehys. Opetusministeriön työryhmämuistioita ja selvityksiä 2009:24. www.minedu. fi/export/sites/default/OPM/Julkaisut/2009/liitteet/tr24.pdf

Raij K (2003) Osaamisen tuottaminen ammattikorkeakoulun päämääränä. Teoksessa $\mathrm{H}$ Kotila (toim.) Ammattikorkeakoulupedagogiikka. Helsinki: Edita. 42-58.

Saranpää M (2012) Arvostan osaamista. Arvioin osaamisia. Kriteerien kriteerit. Teoksessa H Kotila, K Mäki (toim.) Ammattikorkeakoulupedagogiikka 2. Helsinki: Edita. 67-88.

Townsend E, Polatajko H (2013) Enabling occupation II: advancing an occupational therapy vision for health, well-being, \& justice through occupation. 2nd ed. Ottawa, Ontario: Canadian Association of Occupational Therapists.

WFOT Word Federation of Occupational Therapists (http://www.wfot.org) 